\title{
Influence of transglutaminase treatment on properties of micellar casein and products made therefrom
}

\author{
John S. MOUNSEY*, Brendan T. O’KENNEDY, Philip M. KELLY \\ Teagasc, Dairy Products Research Centre, Moorepark, Fermoy, Co. Cork, Ireland
}

Published online 5 July 2005

\begin{abstract}
This work investigated the effect of transglutaminase on (1) micellar casein (phosphocasein) suspensions at $\mathrm{pH} 6.7$; (2) gel formation at $\mathrm{pH} 4.6$; and (3) viscosity of the subsequently produced sodium caseinates. Micellar casein $\left(25 \mathrm{~g}\right.$ protein $\cdot \mathrm{kg}^{-1}$ in simulated milk ultrafiltrate, $\mathrm{pH}$ 6.7) was incubated with and without $1 \%$ microbial transglutaminase (Tgase) at $40{ }^{\circ} \mathrm{C}$ for $5-60 \mathrm{~min}$, prior to thermal inactivation $\left(78^{\circ} \mathrm{C} \times 30 \mathrm{~min}\right)$. The particle size of micellar casein incubated with Tgase (mean between treatments of $213 \mathrm{~nm}$ ) was not markedly different from the control micellar casein $(195 \mathrm{~nm})$, indicating very little inter-micellar cross-linking. Heat stability was markedly improved at $\mathrm{pH}>6.8$ following incubation with Tgase. When Tgase was not inactivated prior to acidification gels were markedly stronger. The maximum in casein hydration $(\mathrm{pH} 5.2-5.5)$ and $\tan \delta(\mathrm{pH} 5.0)$ were eliminated by the action of Tgase indicating a loss of casein mobility. In the absence of Tgase, a sodium caseinate suspension had a low apparent viscosity of $7.6 \mathrm{mPa} \cdot \mathrm{s}\left(100 \mathrm{~s}^{-1}\right)$ with Newtonian behaviour, low turbidity $\left(\mathrm{A}_{600 \mathrm{~nm}}=0.28\right.$ and an ethanol stability of $\left.530 \mathrm{~mL} \cdot \mathrm{L}^{-1}\right)$. Sodium caseinate could not be produced where the Tgase was active during the acidification step. Sodium caseinate made from micellar casein treated with Tgase $(5 \mathrm{~min})$ showed increased viscosity $(64.6 \mathrm{mPa} \cdot \mathrm{s}$ at $\left.100 \mathrm{~s}^{-1}\right)$, turbidity $\left(\mathrm{A}_{600 \mathrm{~nm}}=1.37\right)$ and ethanol stability $\left(621 \mathrm{~mL} \cdot \mathrm{L}^{-1}\right)$. With the exertion of proper control, Tgase can improve some of the functional properties of micellar casein or its sodium caseinate derivative.
\end{abstract}

\section{high viscosity / sodium caseinate / transglutaminase / milk protein}

Résumé - Influence de la transglutaminase sur les propriétés de la caséine micellaire et de ses produits dérivés. L'effet de la transglutaminase sur (1) des suspensions de caséine micellaire (phosphocaséine) à $\mathrm{pH} \mathrm{6,7;} \mathrm{(2)} \mathrm{la} \mathrm{formation} \mathrm{de} \mathrm{gel} \mathrm{à} \mathrm{pH} 4,6$; et (3) la viscosité du caséinate de sodium obtenu par la suite, était étudié. La caséine micellaire $\left(25 \mathrm{~g}\right.$ protéine $\cdot \mathrm{kg}^{-1}$ dans un ultrafiltrat de lait simulé, pH 6,7) était incubée en présence ou non de $1 \%$ de transglutaminase (Tgase) d'origine microbienne à $40{ }^{\circ} \mathrm{C}$ pendant $5-60 \mathrm{~min}$, avant inactivation thermique $\left(78^{\circ} \mathrm{C} \times 30 \mathrm{~min}\right)$. $\mathrm{La}$ taille des particules de caséine micellaire incubée avec la Tgase (moyenne de $213 \mathrm{~nm}$ entre traitements) n'était pas considérablement différente de celle du contrôle de caséine micellaire $(195 \mathrm{~nm})$, indiquant de très faibles liaisons inter-micellaires. La stabilité thermique était considérablement améliorée à $\mathrm{pH}>6,8$ après incubation avec la Tgase. Quand la Tgase n'était pas inactivée avant acidification, les gels étaient considérablement plus forts. Les maxima d'hydratation de la caséine (pH 5,2-5,5) et $\tan \delta(\mathrm{pH} 5,0)$ étaient éliminés par l'action de la Tgase indiquant une perte de mobilité de la caséine. En absence de Tgase, une suspension de sodium de caséinate avait une faible viscosité apparente de $7,6 \mathrm{mPa} \cdot \mathrm{s}\left(100 \mathrm{~s}^{-1}\right)$ avec un comportement Newtonien, une faible turbité $\left(\mathrm{A}_{600 \mathrm{~nm}}=\right.$ 0,28 ) et une stabilité à l'éthanol de $530 \mathrm{~mL} \cdot \mathrm{L}^{-1}$. Le caséinate de sodium ne pouvait être produit

\footnotetext{
* Corresponding author: jmounsey@ moorepark.teagasc.ie
} 
lorsque la Tgase était active durant l'étape d'acidification. Le caséinate de sodium obtenu à partir de caséine micellaire traitée avec la Tgase (5 min) montrait une viscosité $\left(64,6 \mathrm{mPa} \cdot \mathrm{s}\right.$ à $\left.100 \mathrm{~s}^{-1}\right)$, une turbidité $\left(\mathrm{A}_{600 \mathrm{~nm}}=1,37\right)$ et une stabilité à l'éthanol $\left(621 \mathrm{~mL} \cdot \mathrm{L}^{-1}\right)$ plus élevées. Sous des conditions bien contrôlées, la Tgase peut améliorer certaines propriétés fonctionnelles de la caséine micellaire et de son derivé le caséinate de sodium.

viscosité élevée / caséinate de sodium / transglutaminase / protéine laitière

\section{INTRODUCTION}

Transglutaminases (EC 2.3.2.13) are aminoacyltransferases that catalyse acyl transfer reactions from glutamine residues in proteins to primary amines [10]. When the $\varepsilon$-amino group of a lysine residue acts as an acyl acceptor, the two residues are covalently linked through an $\varepsilon$ - $(\gamma$-glutamyl $)$ lysine bond. A prerequisite for the cross-linking reaction with transglutaminase is the availability of sufficient lysines and glutamines for the formation of additional covalent bonds. While most substrate proteins have adequate quantities of these amino acids, their structures can dictate their availability or accessability for reaction.

Milk proteins, especially casein, have the potential to be good substrates for crosslinking by transglutaminase $[6,7,38]$. Cross-linking of proteins results in the formation of dimers, trimers and larger protein polymers. Without any interference, crosslinking will continue until glutamines or lysines become unavailable to the enzyme. Under the appropriate conditions of $\mathrm{pH}$, protein concentration and substrate/enzyme ratio, gelation of the cross-linked protein is often the main effect. Partial cross-linking of proteins requires control of time, enzyme concentration, protein concentration and $\mathrm{pH}$. In addition, the degree of aggregation of the protein substrate prior to incubation with the enzyme may have significant effects on any eventual functionality. Schorsch et al. [36] showed that when transglutaminase was added to skimmed milk at pH 6.7, no gel formation was observed. This inability to gel was attributed to electrostatic and/ or steric repulsion between the protein particles, caused by a layer of $\kappa$-casein on the surface. It was further suggested that this repulsive layer had to be neutralised (through acidification) before gelation became evi- dent. In contrast, Nonaka et al. [28] showed that skim milk suspensions could be turned into self-supporting gels by using appropriate concentrations of transglutaminase and that the breaking strength and hardness of the gels were remarkably enhanced by employing higher enzyme concentrations. However, these authors used 150 g protein $\cdot \mathrm{kg}^{-1}\left(430 \mathrm{~g}\right.$ solids $\left.\cdot \mathrm{kg}^{-1}\right)$ in their suspensions giving closely packed casein micelles, which would undoubtedly have lead to greater opportunities for intermicellar cross-linking compared to the protein concentration $\left(\sim 33 \mathrm{~g} \cdot \mathrm{kg}^{-1}\right)$ of unconcentrated milk. O'Sullivan et al. [31] showed that incubation of skimmed milk or concentrated skimmed milk with Tgase increased heat stability at $\mathrm{pH}$ values of 6.6 or greater. Results indicated that treatment with Tgase prevented the dissociation of $\kappa$-casein from the casein micelles.

Sodium caseinate is a functional milk protein ingredient with good emulsifying properties and water binding properties [19]. Improving the water binding capacity of sodium caseinate dispersions could lead to a more efficient or cost effective use of this food ingredient.

The manufacture of sodium caseinate has been reviewed by Mulvihill [25] and can be subdivided into at least three subprocesses, which are essentially separated by the degree of casein aggregation. The first subprocess involves acidification, either using rapid injection of sufficient mineral acid $(\mathrm{HCl})$ into skim milk at $30^{\circ} \mathrm{C}$, to alter the $\mathrm{pH}$ to approximately 4.6 or, alternatively, lactic casein can be produced through fermentation of the skim milk to the isoelectric point of the casein, giving a slower coagulation but a more natural process. Acidification alters the aggregation state of the casein from its micellar form in milk (itself a complex aggregate of caseins and calcium 
phosphate) to a coagulum of non-dispersible casein aggregates (curd), through a change in balance between electrostatic and hydrophobic forces [11] or steric repulsion [5] on the casein micelle surface. This procedure allows the expulsion of the colloidal calcium phosphate into the milk soluble serum phase. The next step involves washing and concentration of the curd to eliminate the lactose, soluble salts and native whey proteins. The final subprocess, $\mathrm{pH}$ neutralisation with $\mathrm{NaOH}$, is a casein disaggregation process.

Transglutaminase can be added to the casein at any stage of the production process and the degree and type of covalent linkages formed should be influenced by the concentration of casein, its degree of aggregation and the $\mathrm{pH}$. Since cross-linking of casein through its glutamine and lysine residues is an irreversible process, it is important to control the type (inter/intra-protein aggregate linkages) and degree of bond formation.

This paper investigates the effect of transglutaminase on (1) micellar casein suspensions at $\mathrm{pH} 6.7 ;$ (2) curd formation at $\mathrm{pH} 4.6$; and (3) viscosity of the resulting sodium caseinates. The objective of the study was to utilise Tgase-induced proteincross-linking in the formation of high viscosity sodium caseinate, which would have wide applications in products such as low fat spreads, creamers and cream liqueurs.

\section{MATERIALS AND METHODS}

\subsection{Materials}

Calcium-independent transglutaminase (Tgase; Activa ${ }^{\circledR} \mathrm{WM}$ ) was obtained from Ajinomoto Co. Inc. (Tokyo, Japan) containing $990 \mathrm{~g}$ maltodextrin $\cdot \mathrm{kg}^{-1}$ and with a Tgase activity of $81-135 \mathrm{U} \cdot \mathrm{g}^{-1}$ (hydroxamate method; declared by the manufacturer). Micellar casein (phosphocasein; $803 \mathrm{~g}$ protein $\cdot \mathrm{kg}^{-1}, 960 \mathrm{~g}$ casein $\cdot \mathrm{kg}^{-1}$ protein, $19 \mathrm{~g}$ lactose $\cdot \mathrm{kg}^{-1}, 43 \mathrm{~g}$ fat $\cdot \mathrm{kg}^{-1}, 79 \mathrm{~g} \cdot \mathrm{ash} \mathrm{kg}^{-1}$ and $56 \mathrm{~g}$ moisture $\cdot \mathrm{kg}^{-1}$ ) was prepared inhouse as described by Kelly et al. [18].
Whey protein isolate (WPI; $933 \mathrm{~g}$ protein $\cdot \mathrm{kg}^{-1}, 8 \mathrm{~g}$ fat $\cdot \mathrm{kg}^{-1}, 17 \mathrm{~g}$ ash $\cdot \mathrm{kg}^{-1}$ and $43 \mathrm{~g}$ moisture $\cdot \mathrm{kg}^{-1}$ ) was obtained from Davisco International Inc. (Le Seuer, Minnesota, USA). Distilled deionised water was used in all cases for dispersion of samples. 1,5-Glucono-delta-lactone (GDL) was obtained from Fischer Scientific (Leicestershire, UK). All chemicals were Analar grade and supplied by BDH (Poole, England). Absolute ethanol was obtained from Merck KgaA, Darmstadt, Germany.

\subsection{Preparation of protein dispersions}

Micellar casein was dispersed (25 or $50 \mathrm{~g}$ protein $\cdot \mathrm{kg}^{-1}$ ) in distilled de-ionised water, or in lactose-free simulated milk ultrafiltrate (SMUF, Jenness and Koops [16]) containing the specified salts (SMUF) or double the specified salts (SMUF $\times 2)$ normally present in milk [1]. The dispersion of micellar casein in SMUF or SMUF $\times 2$ was undertaken at $5{ }^{\circ} \mathrm{C}$ to avoid precipitation of calcium phosphate. The $\mathrm{pH}$ of samples was adjusted to 6.7 at $22{ }^{\circ} \mathrm{C}$ with $1 \mathrm{~mol} \cdot \mathrm{L}^{-1} \mathrm{HCl}$ or $\mathrm{NaOH}$, and samples were used immediately. Additional mixtures were prepared of micellar casein and whey protein ( 25 and $5 \mathrm{~g}$ protein $\cdot \mathrm{kg}^{-1}$, respectively) in SMUF, micellar casein and whey protein (40 and $10 \mathrm{~g}$ protein $\cdot \mathrm{kg}^{-1}$, respectively) in SMUF.

Samples were incubated with 5,10 or $20 \mathrm{~g}$ Tgase $\cdot \mathrm{kg}^{-1}$ at $40{ }^{\circ} \mathrm{C}$ for $1 \mathrm{~min}-24 \mathrm{~h}$ and with/without heat treatment. Heated samples were immediately placed in a water bath at $78^{\circ} \mathrm{C}$ for $30 \mathrm{~min}$ to inactivate the enzyme and subsequently cooled to $22{ }^{\circ} \mathrm{C}$. This heat treatment is the same as used by Murphy et al. [26] on $\beta$-lactoglobulin solutions to provide maximal exposure of reactive thiol (-SH) groups and should have been sufficient to inactivate the Tgase, which inactivates in less than $1 \mathrm{~min}$ at $80^{\circ} \mathrm{C}$ [36]. Control samples had no enzyme addition and/or heat treatment. The preparation of all dispersions and subsequent analyses on them were carried out in duplicate. Standard deviations given in the text relate to variation between treatment means. 


\subsection{Particle size analysis of micellar casein}

Particle size analysis was undertaken on samples diluted in SMUF at a pH of 6.60 and at $22{ }^{\circ} \mathrm{C}$ was performed using a Malvern Zetamaster (model 7EM; Malvern Instruments Ltd, Worcester, UK) according to the method of O'Kennedy et al. [29].

\subsection{Electrophoresis of micellar casein}

Sodium dodecyl sulphate-polyacrylamide gel electrophoresis (SDS-PAGE) was performed by the method of Laemmli [20]. A stacking gel (40 $\mathrm{g}$ acrylamide $\cdot \mathrm{kg}^{-1}$; acrylamide: bisacrylamide ratio, 37.5:1) and a separating gel (125 g acrylamide $\cdot \mathrm{kg}^{-1}$; acrylamide: bisacrylamide ratio, 37.5:1) were prepared and run on a Biorad mini Protean ${ }^{\circledR}$ II apparatus (Bio-Rad Laboratories, Hemel Hempstead, Hertfordshire, UK) with miniature gels $(70 \times 80 \times 0.75 \mathrm{~mm})$. Protein samples $\left(12.5 \mathrm{~g}\right.$ protein $\left.\cdot \mathrm{L}^{-1}\right)$ were diluted (1:4 ratio) in $1 \mathrm{~mL}$ of sample buffer and $4 \mu \mathrm{L}$ samples were loaded using a microsyringe (Hamilton 710, Reno, Nevada, USA). Protein markers, ranging in molecular weight from 14.4 to $94 \mathrm{~kg} \cdot \mathrm{mol}^{-1}$ (Sigma Marker M4048; Sigma Chemicals, St. Louis, MO) were also run on the gel. Samples were run through the stacking and separating gels at 120 and $155 \mathrm{~V}$, respectively. The gels were stained for $1 \mathrm{~h}$ in a $1-\mathrm{g} \cdot \mathrm{L}^{-1}$ Coomassie brilliant blue G250 and destained in a $100-\mathrm{mL}$ isopropanol. $\mathrm{L}^{-1}$, $100-\mathrm{mL}$ acetic acid $\cdot \mathrm{L}^{-1}$ solution.

\subsection{Casein solvation, calcium and phosphorus determination}

Samples were adjusted to $\mathrm{pH}$ values in the range of $6.8-4.8$ with $1 \mathrm{~mol} \cdot \mathrm{L}^{-1} \mathrm{HCl}$ or $\mathrm{NaOH}$. Samples were then centrifuged (Sorvall ultracentrifuge, Du Pont, OTD 65B) for $120 \mathrm{~min}$ at $18^{\circ} \mathrm{C}$ at $78000 \times g$. The supernatant was decanted, the centrifuge tubes inverted and the pellet drained in this position for $1 \mathrm{~h}$ before freeze-drying. The difference in pellet weight before and after freeze-drying at $-47^{\circ} \mathrm{C}$ for $2.5 \mathrm{~d}$ (Labconco, vacuum: $70 \times 10^{-3}$ mbar) was determined and the number was divided by the dried pellet weight to give the pellet solvation ( $\mathrm{g} \mathrm{H}_{2} \mathrm{O} \cdot \mathrm{g}-1$ dried pellet) [3]. The supernatant was then analysed for calcium, by atomic absorption following protein precipitation using trichloroacetic acid (TCA; final concentration of TCA, $120 \mathrm{~g} \cdot \mathrm{kg}^{-1}$ ) and phosphorus [13].

\subsection{Heat stability of micellar casein with/without whey protein}

Sample solutions were prepared at various $\mathrm{pH}$ values in a range of 6.1 to 7.1 by adjustment with $0.5 \mathrm{~mol} \cdot \mathrm{L}^{-1} \mathrm{HCl}$ or $\mathrm{NaOH}$. Samples were equilibrated overnight at $5{ }^{\circ} \mathrm{C}$ before measuring $\mathrm{pH}$ values at $22{ }^{\circ} \mathrm{C}$ prior to testing. Heat stability was assessed by a modification of the test of Davies and White [4]. Samples (3.5 mL) were enclosed into a narrow glass tube, which was inserted into a swinging rack placed in a temperature controlled oil-bath (Elbanton, 5331 EJ Kerkdriel, Holland) at $120{ }^{\circ} \mathrm{C}\left(50 \mathrm{~g} \cdot \mathrm{kg}^{-1}\right.$ protein) or $140{ }^{\circ} \mathrm{C}\left(25 \mathrm{~g}\right.$ protein $\left.\cdot \mathrm{kg}^{-1}\right)$. The samples in the oil-bath were rocked ( 8 oscillations $\cdot \mathrm{min}^{-1}$ ). HCT (heat coagulation time) was defined as the time for visual coagulation to occur.

\subsection{Acid gelation of micellar casein with/without whey protein}

The storage modulus ( $\left.\mathrm{G}^{\prime}\right)$, loss modulus $\left(G^{\prime}\right.$ ') and $\tan \delta$ (loss tangent; G', G') during acidification of the protein solutions were determined at $40{ }^{\circ} \mathrm{C}$ using a Bohlin CVO Rheometer (Bohlin, Cirencester, UK) according to the method of Walsh-O'Grady et al. [46]. GDL was added at levels of 20 or $26 \mathrm{~g} \cdot \mathrm{kg}^{-1}$ to dispersions of micellar casein $\left(50 \mathrm{~g}\right.$ protein $\left.\cdot \mathrm{kg}^{-1}\right)$ in water or SMUF $\times 2$, respectively, to reach a $\mathrm{pH}$ of 4.6 in $120 \mathrm{~min}$. Dispersions of micellar casein (40 g protein $\left.\cdot \mathrm{kg}^{-1}\right)$ and WPI (10 g protein $\cdot \mathrm{kg}^{-1}$ ) in SMUF required $23 \mathrm{~g} \cdot \mathrm{kg}^{-1}$ of GDL. The gel point was defined as the $\mathrm{pH}$ where the $G$ ' reached a value greater than 1.0 $\mathrm{Pa}$. The final gel strength was defined as $\mathrm{G}^{\prime}$ after $120 \mathrm{~min}$. 


\subsection{Preparation of high viscosity sodium caseinate}

Micellar casein $\left(25 \mathrm{~g}\right.$ protein $\left.\cdot \mathrm{kg}^{-1}\right)$ in SMUF was incubated with Tgase $\left(10 \mathrm{~g} \cdot \mathrm{kg}^{-1}\right)$ for $5,10,30$ or $60 \mathrm{~min}$ at $40^{\circ} \mathrm{C}$ in a water bath. A sample without added Tgase was used as a control. Samples were immediately placed in a water bath at $78^{\circ} \mathrm{C}$ for $30 \mathrm{~min}$ to inactivate the enzyme. On subsequent cooling to $40^{\circ} \mathrm{C}$, samples were $\mathrm{pH}$ adjusted to 4.6 using $1 \mathrm{~mol} \cdot \mathrm{L}^{-1} \mathrm{HCl}$ and the precipitated protein was collected by centrifugation $(2461 \times g, 20 \mathrm{~min})$ at $20^{\circ} \mathrm{C}$ using a Mistral MSE 3000I centrifuge (Sanyo Gallenkamp, Loughborough, U.K.). The precipitate was washed with distilled water and re-centrifuged 2 times, prior to adding more distilled water (bringing the solids content by calculation to approximately $70 \mathrm{~g}$ solids $\cdot \mathrm{kg}^{-1}$ ) and readjusting the $\mathrm{pH}$ to $7.0 \mathrm{using} 1 \mathrm{~mol} \cdot \mathrm{L}^{-1} \mathrm{NaOH}$. Samples were analysed for moisture [12], and assuming a protein content of $960 \mathrm{~g}$ casein $\cdot \mathrm{kg}^{-1}$ solids, the protein content of the sodium caseinate was adjusted to $50 \mathrm{~g} \cdot \mathrm{kg}^{-1}$. This was corroborated by assaying for moisture and protein [14] on neutralised caseinate samples that were freeze-dried at $-47^{\circ} \mathrm{C}$ for $2.5 \mathrm{~d}$ (Labconco, vacuum: $70 \times 10^{-3} \mathrm{mbar}$ ).

\subsection{Viscosity determination of sodium caseinate}

Viscosity was measured using a controlled stress Bohlin CVO rheometer (Bohlin Instruments, Cirencester, UK). A concentric cylinder (C25) measurement system with a bob diameter $25 \mathrm{~mm}$ and an internal diameter of the cup of $27.5 \mathrm{~mm}$. All measurements were taken at $22{ }^{\circ} \mathrm{C}$. Sufficient stress was applied to the sample to attain a pre-shear rate of $200 \mathrm{~s}^{-1}$, which was applied for $30 \mathrm{~s}$. A shear rate sweep from 200 to $10 \mathrm{~s}^{-1}$ was applied over $4 \mathrm{~min}$ and the apparent viscosity $(\mathrm{mPa} \cdot \mathrm{s})$ of the sample was taken at a shear rate of $100 \mathrm{~s}^{-1}$.

\subsection{Ethanol stability and turbidity determination of sodium caseinate}

Ethanol stability and turbidity of sodium caseinate $\left(10 \mathrm{~g}\right.$ protein $\left.\cdot \mathrm{kg}^{-1}\right)$ dispersions were determined according to the methods of O'Kennedy et al. [30]. Following coagulation with ethanol, samples were filtered with Whatman no. 42 filter paper and the protein content of the supernatant (ethanol soluble fraction) was determined by UV absorption at $280 \mathrm{~nm}$ using extinction coefficient of $0.81 \mathrm{~mL} \cdot \mathrm{mg}^{-1} \cdot \mathrm{cm}^{-1}$ [34].

\section{RESULTS AND DISCUSSION}

\subsection{Effect of Tgase on the properties of micellar casein at pH 6.7}

Untreated micellar casein (25 g protein $\cdot \mathrm{kg}^{-1}$ ) had an average particle size of $195 \pm 3 \mathrm{~nm}$. Particle size of micellar casein (25 g protein $\cdot \mathrm{kg}^{-1}$ ) incubated with 10 g.Tgase $\cdot \mathrm{kg}^{-1}$ for $5-60 \mathrm{~min}$ showed little variation with a mean and standard deviation between treatments of 213 and $3 \mathrm{~nm}$, respectively. While this is an $8 \%$ average difference in particle size it could be attributed to the effect of heating on untreated micellar casein. Similar particle sizes were obtained by Vasbinder et al. [45] for Tgasetreated micellar casein in water. In agreement with Faergemand and Qvist [7], this would suggest that enzyme-induced intermicellar cross-linking is not a major occurrence under these conditions of $\mathrm{pH}$, ionic strength, protein concentration and aggregation-state.

In agreement with these particle size results and the findings of Schorsch et al. [36], dynamic rheological evaluation of Tgase-incubated micellar casein (results not shown) showed the absence of gelation at neutral $\mathrm{pH}$.

SDS-PAGE of micellar casein treated with Tgase at $\mathrm{pH} 6.7$ for up to $24 \mathrm{~h}$ (Fig. 1) showed gradual reduction in $\alpha_{s^{-}}, \beta$ - and $\kappa-$ casein bands over time with the formation of a band of protein on top of the stacking gel. These results are in agreement with previous findings [32, 33] and indicate that intra-micellar Tgase-mediated cross-linking was occurring, the extent of which was obviously time-dependent.

The effect of Tgase $\left(10 \mathrm{~g} \cdot \mathrm{kg}^{-1}\right)$ on the $\mathrm{HCT} / \mathrm{pH}$ profile of micellar casein $(25 \mathrm{~g}$ protein $\cdot \mathrm{kg}^{-1}$ ) in SMUF at $140{ }^{\circ} \mathrm{C}$ is outlined 


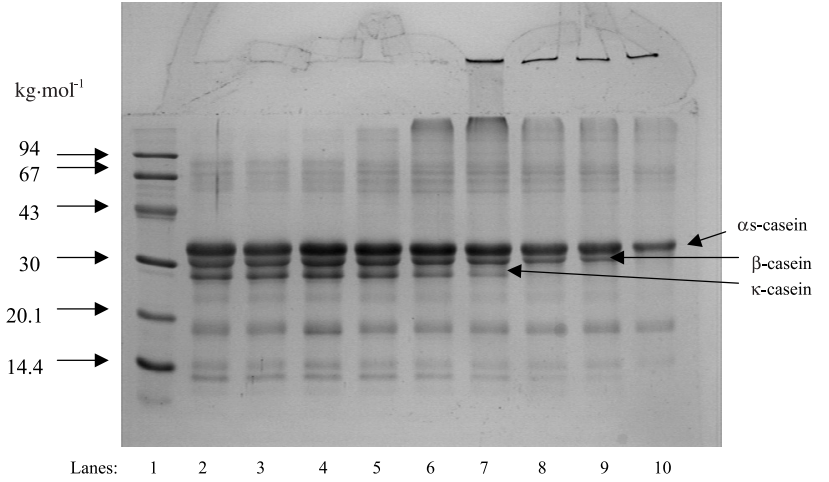

Figure 1. SDS-PAGE profiles of Tgase-catalysed polymerisation of micellar casein $(25 \mathrm{~g}$ protein $\mathrm{kg}^{-1}$ ) dispersions in SMUF. Lane 1, protein markers; lane 2, micellar casein ( $25 \mathrm{~g}$ protein $\cdot \mathrm{kg}^{-1}$ ) dispersions in SMUF without Tgase addition, lanes 3-10, micellar casein $\left(25 \mathrm{~g}\right.$ protein $\left.\cdot \mathrm{kg}^{-1}\right)$ dispersions in SMUF incubated with $5 \mathrm{~g} \cdot \mathrm{kg}^{-1}$ of Tgase at $40{ }^{\circ} \mathrm{C}$ for $1 \mathrm{~min}, 5 \mathrm{~min}, 15 \mathrm{~min}, 30 \mathrm{~min}$, $1 \mathrm{~h}, 2 \mathrm{~h}, 8 \mathrm{~h}$ or $24 \mathrm{~h}$, respectively.

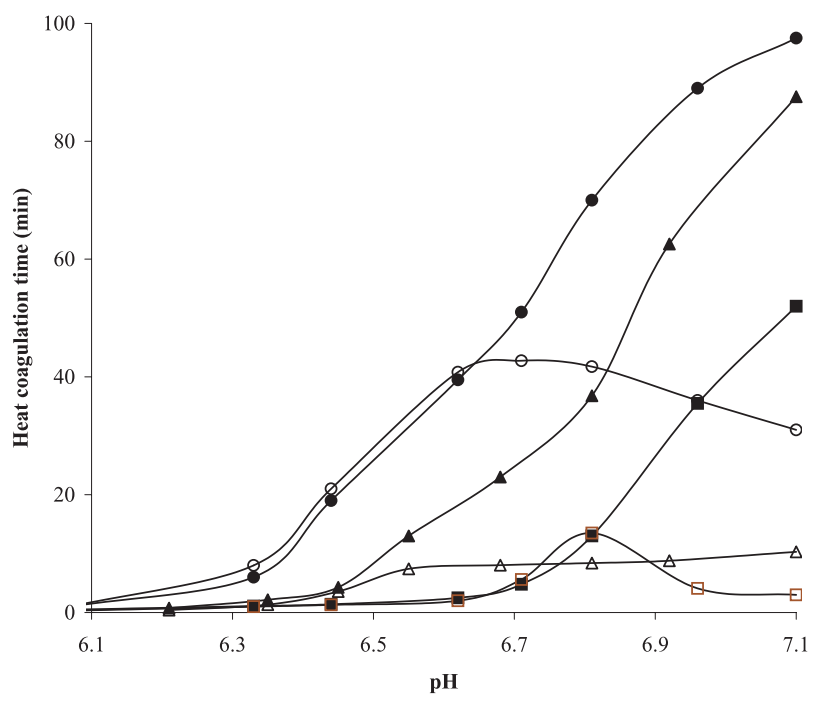

Figure 2. HCT/pH profile at $140{ }^{\circ} \mathrm{C}$ of micellar casein $\left(25 \mathrm{~g}\right.$ protein $\left.\cdot \mathrm{kg}^{-1}\right)$ in $\operatorname{SMUF}(\Delta)$, micellar casein $\left(25 \mathrm{~g}\right.$ protein $\left.\cdot \mathrm{kg}^{-1}\right)$ in SMUF $\left(10 \mathrm{~g} \cdot \mathrm{kg}^{-1}\right.$ Tgase, $60 \mathrm{~min}, 40^{\circ} \mathrm{C}$ prior to enzyme inactivation at $78^{\circ} \mathrm{C}$ for $\left.30 \mathrm{~min}\right)(\mathbf{\Delta})$, micellar casein $\left(25 \mathrm{~g}\right.$ protein $\left.\cdot \mathrm{kg}^{-1}\right) / \mathrm{WPI}\left(5 \mathrm{~g}\right.$ protein $\left.\cdot \mathrm{kg}^{-1}\right)$ mixtures in SMUF $(\square)$ or micellar casein $\left(25 \mathrm{~g}\right.$ protein $\left.\cdot \mathrm{kg}^{-1}\right) /$ WPI $\left(5 \mathrm{~g}\right.$ protein $\left.\cdot \mathrm{kg}^{-1}\right)$ mixtures in SMUF $\left(10 \mathrm{~g} \cdot \mathrm{kg}^{-1}\right.$ Tgase, $60 \mathrm{~min}, 40{ }^{\circ} \mathrm{C}$ prior to enzyme inactivation at $78^{\circ} \mathrm{C}$ for $\left.30 \mathrm{~min}\right)(\boldsymbol{\square}) ; \mathrm{HCT} / \mathrm{pH}$ profile at $120^{\circ} \mathrm{C}$ of micellar casein $\left(50 \mathrm{~g}\right.$ protein $\left.\cdot \mathrm{kg}^{-1}\right)$ in SMUF $\times 2$ (O) or micellar casein $\left(50 \mathrm{~g}\right.$ protein $\left.\cdot \mathrm{kg}^{-1}\right)$ in SMUF $\times 2\left(20 \mathrm{~g} \cdot \mathrm{kg}^{-1} \mathrm{Tgase}, 60 \mathrm{~min}, 40{ }^{\circ} \mathrm{C}\right.$ prior to enzyme inactivation at $78{ }^{\circ} \mathrm{C}$ for $\left.30 \mathrm{~min}\right)$ Each curve represents the mean of duplicate trials.

in Figure 2. The HCT of the control increased from a minimum value of $0.5 \mathrm{~min}$ at $\mathrm{pH} 6.21$ to $10.3 \mathrm{~min}$ at $\mathrm{pH} 7.10$. The increase in $\mathrm{HCT}$ with increasing $\mathrm{pH}$ range is in agreement with the findings of O'Sullivan et al. [32] for serum protein-free milk dispersed in SMUF and urea (at milk levels).
However, the latter authors found a more dramatic increase in HCT at alkaline $\mathrm{pH}$ values, which may be partly due to the presence of added urea (no urea was added in the current work). Muir and Sweetsur [24] showed the addition of urea increased the HCT of milk. Incubation with Tgase, prior 
to heat stability evaluation showed little difference in HCT up to $\mathrm{pH} 6.45$, but above this $\mathrm{pH}, \mathrm{HCT}$ was dramatically increased reaching a HCT of $87.6 \mathrm{~min}$ at $\mathrm{pH} 7.10$. The effect of Tgase in increasing the HCT in the alkali $\mathrm{pH}$ range is in agreement with the work of O'Sullivan et al. [32] on Tgasetreated micellar casein in SMUF (no whey proteins). The formation of cross-links restricted the movement of casein from the colloidal to the serum phase, which in turn probably restricted the solubilisation of micellar $\kappa$-casein on heat treatment [32].

Similar effects at alkaline $\mathrm{pH}$ were observed for micellar casein concentrates $\left(50 \mathrm{~g}\right.$ protein $\cdot \mathrm{kg}^{-1}, 120^{\circ} \mathrm{C}$ ) where the milk salts were increased (SMUF $\times 2)$ in proportion to the casein concentration (Fig. 2). In the absence of Tgase a maximum in the $\mathrm{HCT} / \mathrm{pH}$ profile was observed at $\mathrm{pH} 6.71$, leading to a reduction in HCT at more alkaline $\mathrm{pH}$ values. It has previously been shown that reconstituted concentrated skim milk (225-245 g solids $\cdot \mathrm{kg}^{-1}$ ) also had a HCT maximum at $\mathrm{pH} \sim 6.5-6.6[27,31]$. The maximum in the $\mathrm{HCT} / \mathrm{pH}$ profile of concentrated micellar casein dispersed in SMUF $\times 2$ may be attributed to a concentration effect as shown for concentrated reconstituted skim milk by increased partitioning (supersaturation) of both calcium and phosphate into the colloidal phase [27] and increased partitioning of $\kappa$-casein into the serum phase, particularly at alkaline $\mathrm{pH}$ [39]. Incubation with Tgase eliminated this HCT maximum resulting in marked increases in heat stability in the alkaline $\mathrm{pH}$ range, which is in agreement with the findings of O'Sullivan et al. [31] for Tgase-treated concentrated reconstituted skim milk.

The inclusion of whey proteins ( $5 \mathrm{~g}$ protein $\cdot \mathrm{kg}^{-1}$ ) into micellar casein ( $25 \mathrm{~g}$ protein $\cdot \mathrm{kg}^{-1}$ ) dispersions was also observed to introduce a maximum in the $\mathrm{HCT} / \mathrm{pH}$ profile (Fig. 2). Incubation with Tgase $\left(10 \mathrm{~g} \cdot \mathrm{kg}^{-1}\right)$ was observed to eliminate the maximum and markedly improve the heat stability in the alkaline $\mathrm{pH}$ range. O'Sullivan et al. [31] suggested that treatment of pre-heated milk with Tgase inhibited the dissociation of $\kappa$ casein from the casein micelles, possibly by cross-linking $\kappa$-casein and denatured $\beta$-lactoglobulin resulting in enhanced heat sta- bility of milk at $\mathrm{pH}$ values $>6.5$. Heat stability at the acidic side of the HCT/pH profile is generally recognised as an acidic coagulation [42]. As the $\mathrm{pH}$ of micellar casein or milk is lowered the increased protonation of protein groups decreases the net negative charge of the casein micelle [43] and the amount of $\mathrm{Ca}^{2+}$ ions increases due to the solubilisation of colloidal calcium phosphate $[9,35]$. However, casein micelle stability at acidic $\mathrm{pH}$ is attributed to steric stabilisation by $\kappa$-casein [5]. Vasbinder et al. [45] found that Tgase prevented the release of casein into the serum phase on acidification to $\mathrm{pH}$ 5.3, and attributed it to the formation of irreversible intra-casein linkages. These intra-casein crosslinks, which are associated with increased heat stability at the more alkaline $\mathrm{pH}$ range did not adversely affect the ability of $\kappa$-casein to sterically stabilise at more acidic $\mathrm{pH}$ values.

\subsection{Effect of Tgase on the properties of micellar casein on acidification to $\mathrm{pH} 4.6$}

The casein hydration/pH profiles, as determined by ultracentrifugation, of micellar casein ( $25 \mathrm{~g}$ protein $\cdot \mathrm{kg}^{-1}$ ) in SMUF following incubation with or without Tgase $\left(10 \mathrm{~g} \cdot \mathrm{kg}^{-1}\right)$ are outlined in Figure 3 . In the absence of Tgase, the casein micelle bound $2.43 \pm 0.08 \mathrm{~g} \cdot \mathrm{g}^{-1} \mathrm{H}_{2} \mathrm{O}$ at $\mathrm{pH} 6.8$ and reached a maximum of $2.95 \pm 0.01 \mathrm{~g} \cdot \mathrm{g}^{-1} \mathrm{H}_{2} \mathrm{O}$ at $\mathrm{pH}$ 5.5. This is in agreement with previous findings of a hydration peak at $\mathrm{pH} 5.5$ for casein micelles in skim milk $[40,41]$. The sample incubated with Tgase bound less water $\left(2.06 \pm 0.16 \mathrm{~g} \cdot \mathrm{g}^{-1} \mathrm{H}_{2} \mathrm{O}\right)$ at $\mathrm{pH} 6.8$ and remained generally constant as the $\mathrm{pH}$ was reduced. The greater hydration of the untreated micellar casein, especially at lower $\mathrm{pH}$ values coincided with the solubilisation of colloidal calcium and phosphate allowing the casein micelle to become more hydrated with maximal hydration in the $\mathrm{pH}$ region 5.2-5.6. The solubilisation of calcium and phosphate during acidification was normal, irrespective of Tgase treatment (results not shown). The lack of hydration increases during acidification when micellar casein was treated with Tgase probably indicated that the cross-linking by Tgase of casein within the micelle reduced its hydrating 


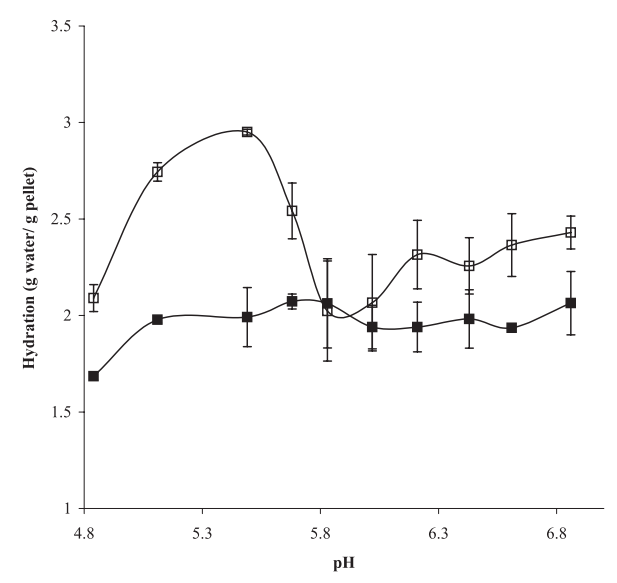

Figure 3. Casein hydration/pH profiles of micellar casein $\left(25 \mathrm{~g}\right.$ protein $\left.\cdot \mathrm{kg}^{-1}\right)$ in SMUF $(\square)$ and micellar casein ( $25 \mathrm{~g}$ protein $\left.\cdot \mathrm{kg}^{-1}\right)$ in SMUF following incubation with Tgase $\left(10 \mathrm{~g} \cdot \mathrm{kg}^{-1}, 60 \mathrm{~min}\right.$ at $40^{\circ} \mathrm{C}$, inactivated at $78^{\circ} \mathrm{C} \times$ $30 \mathrm{~min}$; ). Each curve represents the mean of duplicate trials. Vertical bars show standard deviation between means.

properties, and that calcium and phosphate solubilisation could not induce it.
The acid gelation profile of micellar casein $\left(50 \mathrm{~g}\right.$ protein $\left.\cdot \mathrm{kg}^{-1}\right)$ in SMUF $\times 2$, preincubated with $20 \mathrm{~g} \cdot \mathrm{kg}^{-1}$ Tgase $(5 \mathrm{~min}$ at $40{ }^{\circ} \mathrm{C}, \mathrm{pH}$ 6.7), with/without enzyme inactivation $\left(78{ }^{\circ} \mathrm{C} \times 30 \mathrm{~min}\right)$ is outlined in Figure 4 . Where the enzyme was inactivated following incubation, gelation was initiated $\left(\mathrm{G}^{\prime}>1 \mathrm{~Pa}\right)$ at a $\mathrm{pH}$ of $5.3 \pm 0.03$ reaching a $\mathrm{G}^{\prime}$ of $172 \pm 71 \mathrm{~Pa}$ after $120 \mathrm{~min}$. When Tgase was active during the acidification step, gelation commenced at a similar $\mathrm{pH}$ $(5.28 \pm 0.02)$ but the gel strength was markedly improved $\left(\mathrm{G}^{\prime}{ }_{120 \mathrm{~min}}\right.$ of $\left.432 \pm 157 \mathrm{~Pa}\right)$. Where the enzyme was absent gelation was initiated at $\mathrm{pH} 4.9 \pm 0.03$ having a gel strength of $11.3 \pm 3.9 \mathrm{~Pa}$ after $120 \mathrm{~min}$. On acidification the gel point of micellar casein is determined by the protein concentration and the ionic strength [17]. This has been attributed to the direct effect of ionic strength on the ability of $\kappa$-casein to sterically stabilise the micelle. Micellar casein dispersions incubated with Tgase and with or without subsequently inactivated prior to acidification had the same gelation point (pH 5.3), which was higher than micellar casein dispersions with no added Tgase (pH 4.9). However, the presence of active Tgase during

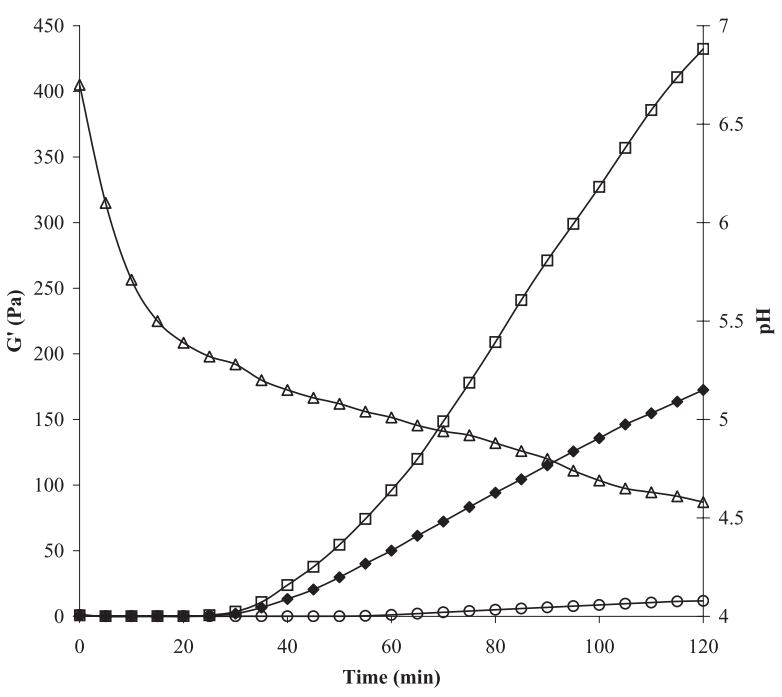

Figure 4. Gel strength of micellar casein $\left(50 \mathrm{~g}\right.$ protein $\left.\cdot \mathrm{kg}^{-1}\right)$ in $\mathrm{SMUF} \times 2(\mathrm{O})$, micellar casein $(50 \mathrm{~g}$ protein $\left.\cdot \mathrm{kg}^{-1}\right)$ in $\mathrm{SMUF} \times 2$ following incubation with Tgase $\left(20 \mathrm{~g} \cdot \mathrm{kg}^{-1}, 5 \mathrm{~min}\right.$ at $\left.40^{\circ} \mathrm{C}, \mathrm{pH} 6.7\right)$ prior to acidification $(\square)$ or micellar casein $\left(50 \mathrm{~g}\right.$ protein $\left.\cdot \mathrm{kg}^{-1}\right)$ in SMUF $\times 2$ following incubation with Tgase $\left(20 \mathrm{~g} \cdot \mathrm{kg}^{-1}, 5 \mathrm{~min}\right.$ at $\left.40^{\circ} \mathrm{C}, \mathrm{pH} 6.7\right)$ followed by enzyme inactivation at $78^{\circ} \mathrm{C}$ for $30 \mathrm{~min}(\bullet)$. Typical $\mathrm{pH}$ curve $(\Delta)$ is included. Each curve represents the mean of duplicate trials. 


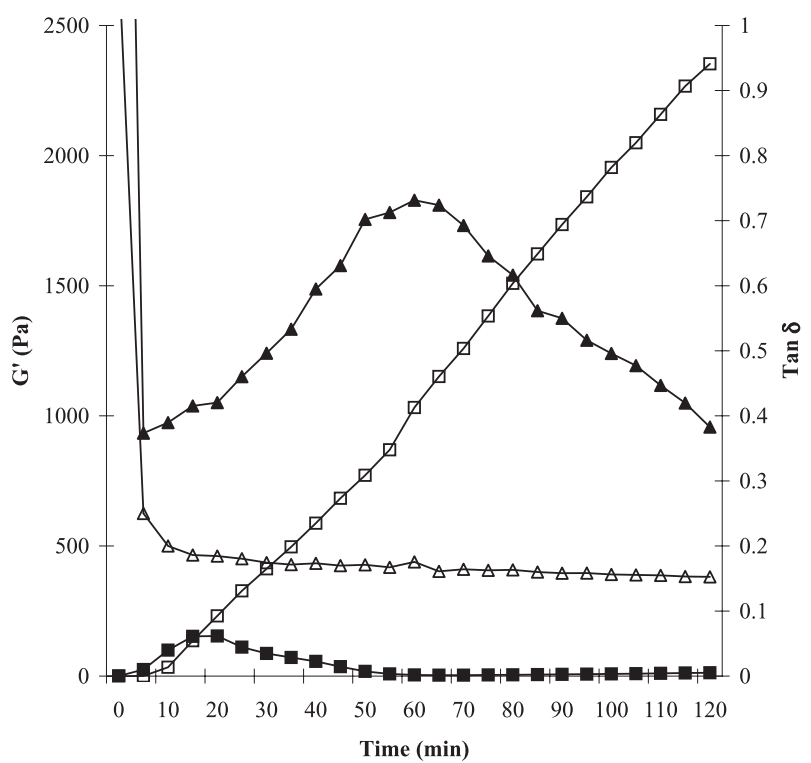

Figure 5. Gel strength on acidification of micellar casein $\left(50 \mathrm{~g}\right.$ protein $\left.\cdot \mathrm{kg}^{-1}\right)$ dispersed in water $\left(\mathrm{G}^{\prime}\right.$ : $\boldsymbol{\square}, \tan \delta: \mathbf{\Lambda})$ or micellar casein $\left(50 \mathrm{~g}\right.$ protein $\left.\cdot \mathrm{kg}^{-1}\right)$ dispersed in water and incubated with Tgase $\left(20 \mathrm{~g} \cdot \mathrm{kg}^{-1}, 5 \mathrm{~min}\right.$ at $40^{\circ} \mathrm{C}, \mathrm{pH}$ 6.7) prior to acidification (G': $\left.\square, \tan \delta: \Delta\right)$. Each curve represents the mean of duplicate trials.

the acidification step markedly increased the final gel strength compared to the situation where the Tgase was inactivated prior to acidification. Lorenzen et al. [22] found markedly increased gel strength in yoghurt (made from whole milk preheated at $92^{\circ} \mathrm{C}$ for $5 \mathrm{~min}$ ) containing active Tgase compared to yoghurt made from preheated skim milk that was incubated with Tgase but with the enzyme then inactivated. The current work suggested that the action of Tgase at neutral $\mathrm{pH}$ (intra-micellar cross-linking) affected the stability of micellar casein to increased acidity (see Fig. 2; lower heat stability) and where present during the acidification process, markedly increased the gel strength through additional cross-linking when a three-dimensional casein matrix was formed.

The acid gelation profile of micellar casein $\left(50 \mathrm{~g}\right.$ protein $\left.\cdot \mathrm{kg}^{-1}\right)$ dispersed in water is outlined in Figure 5. Gelation commenced at $\mathrm{pH} 6.18 \pm 0.04$, reached a peak in gel strength after $15 \mathrm{~min}(154.2 \pm 69 \mathrm{~Pa})$ before gel strength decreased with increased acidification and the gel strength after $120 \mathrm{~min}$ was only $13 \pm 11.9 \mathrm{~Pa}$. This profile is typical of low ionic strength micellar casein dispersions [1], however, when Tgase was added and active during the acidification step, gelation commenced at a lower $\mathrm{pH}(6.01 \pm$ 0.04 ) but the gel strength increased to $2235 \mathrm{~Pa}$ after $120 \mathrm{~min}$. In addition, no maximum in the $\tan \delta$ profile was observed in the presence of Tgase. A high tan $\delta$ suggests that the average lifetime of the protein-protein bonds is rather small and that rearrangements can occur [44]. The very high $\tan \delta$ observed for acid gels produced from micellar casein dispersed in water and an associated maximum at $\mathrm{pH} 5.0$ suggested that the premature gel point $(\mathrm{pH} 6.2)$ observed under low ionic strength conditions led to massive rearrangement of casein particles. In the presence of Tgase the gel point still occurred at high $\mathrm{pH}$ values but the low absolute value of $\tan \delta$ and the absence of a maximum led to a high final gel strength (Fig. 5). 


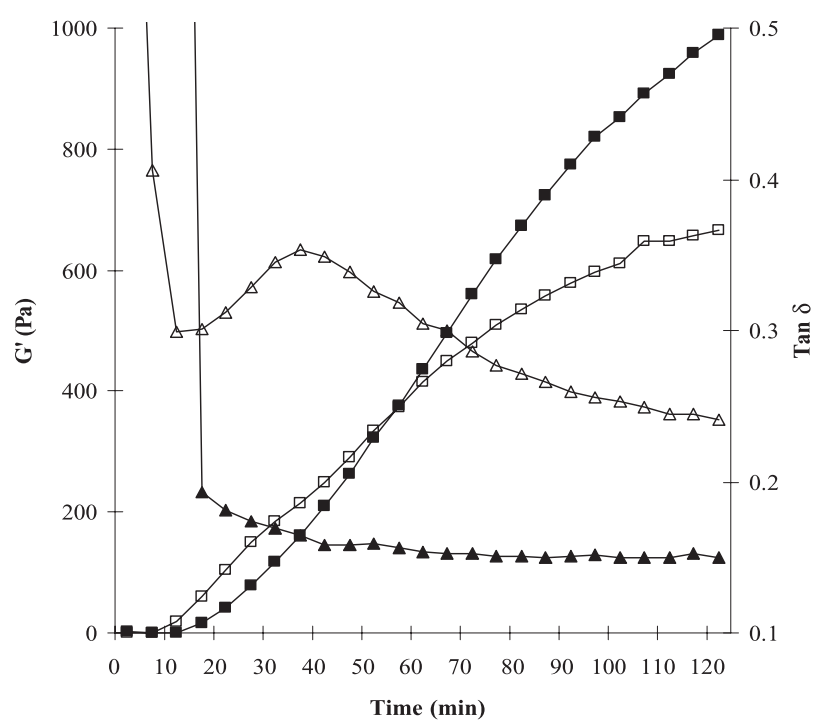

Figure 6. Gel strength of micellar casein $\left(40 \mathrm{~g}\right.$ protein $\left.\cdot \mathrm{kg}^{-1}\right) /$ WPI $\left(10 \mathrm{~g}\right.$ protein $\left.\cdot \mathrm{kg}^{-1}\right)$ mixtures in SMUF which had been preheated at $90^{\circ} \mathrm{C} \times 20$ min prior to acidification ( $G^{\prime}: \square, \tan \delta: \Delta$ ) or micellar casein $\left(40 \mathrm{~g}\right.$ protein $\left.\cdot \mathrm{kg}^{-1}\right) /$ WPI $\left(10 \mathrm{~g}\right.$ protein $\left.\cdot \mathrm{kg}^{-1}\right)$ mixtures in SMUF which had been preheated at $90{ }^{\circ} \mathrm{C} \times 20 \mathrm{~min}$ and incubated with Tgase $\left(20 \mathrm{~g} \cdot \mathrm{kg}^{-1}, 5 \mathrm{~min}\right.$ at $\left.40{ }^{\circ} \mathrm{C}, \mathrm{pH} 6.7\right)$ prior to acidification $\left(G^{\prime}: \mathbf{\square}, \tan \delta: \mathbf{\Delta}\right)$. Each curve represents the mean of duplicate trials.

The acid gelation profile of preheated micellar casein $\left(40 \mathrm{~g}\right.$ protein $\left.\cdot \mathrm{kg}^{-1}\right)$, whey protein $\left(10 \mathrm{~g}\right.$ protein $\left.\cdot \mathrm{kg}^{-1}\right)$ mixtures are outlined in Figure 6. Note that the mixtures were dispersed in SMUF, and not SMUF×2, to initiate the gelation at a higher $\mathrm{pH}$ thus enhancing rearrangement between protein strands. This mixture was used as a model system to understand the effect of Tgase on the acid gel formation of yoghurt.

In the absence of Tgase the gel point therefore occurred at $\mathrm{pH} 5.90 \pm 0.01$ and reached a G' of $665.8 \pm 141 \mathrm{~Pa}$ after $120 \mathrm{~min}$. However, when Tgase $\left(20 \mathrm{~g} \cdot \mathrm{kg}^{-1}\right)$ was present and active during acidification, gelation occurred at a lower $\mathrm{pH}(5.69 \pm$ 0.02 ) but the gel strength was increased to $989 \pm 115 \mathrm{~Pa}$ after $120 \mathrm{~min}$. The tan $\delta$ profile during acidification of pre-heated micellar casein/ WPI mixtures in SMUF had a maximum at $\mathrm{pH} 5.03 \pm 0.04$, which was similar to that in acid gels formed from heated skim milk [20]. The solubilisation of calcium phosphate has been suggested to partially loosen the bonds between the protein particles in the acid gel network resulting in the maximum in $\tan \delta[22]$. No such $\tan \delta$ maximum was observed when incubated with Tgase.

A number of authors have shown increases in gel strength of yoghurt samples from Tgase-treated milk [8, 21, 22]. Imm et al. [15] found a marked increase in G' of acid gels formed from re-constituted Tgasetreated skim milk powder compared to a control, which had no Tgase treatment. These authors obtained a phase angle $(\delta)$ maximum at $\mathrm{pH}$ of $\sim 5.0$ for the control, which corresponds with the $\tan \delta$ maximum obtained during acidification of pre-heated micellar casein/WPI mixtures in SMUF in the current work. Throughout acidification, the Tgase-treated sample had lower phase angles than the control indicating greater elasticity in the former with a more ordered network [15]. In agreement with the present work, no phase angle maximum at $\mathrm{pH} 5.0$ was observed when incubated with Tgase. 


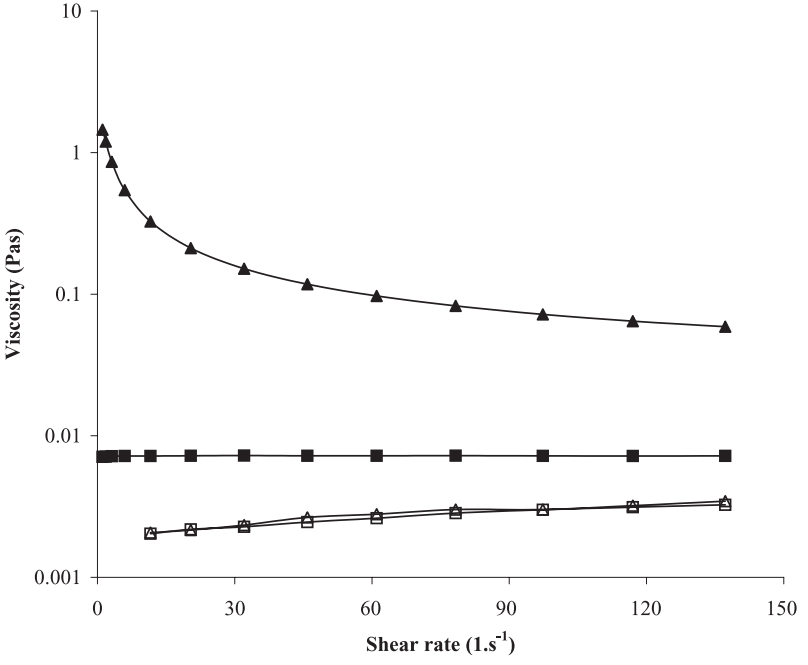

Figure 7. Viscosity profile of micellar casein $(25 \mathrm{~g}$ protein $\cdot \mathrm{kg}^{-1}$ ) in SMUF ( $\square$ ), Tgase $\left(10 \mathrm{~g} \cdot \mathrm{kg}^{-1}, 5 \mathrm{~min}\right.$ at $40^{\circ} \mathrm{C}, \mathrm{pH}$ 6.7 before inactivation at $78^{\circ} \mathrm{C}$ for $30 \mathrm{~min}$ )-treated micellar casein $\left(25 \mathrm{~g}\right.$ protein $\left.\cdot \mathrm{kg}^{-1}\right)$ in SMUF $(\Delta)$, sodium caseinate (50 g protein $\cdot \mathrm{kg}^{-1}$ ) made from micellar casein $\left(25 \mathrm{~g}\right.$ protein $\left.\cdot \mathrm{kg}^{-1}\right)$ in SMUF ( $)$ or sodium caseinate $\left(50 \mathrm{~g}\right.$ protein $\left.\cdot \mathrm{kg}^{-1}\right)$ made from Tgase $\left(10 \mathrm{~g} \cdot \mathrm{kg}^{-1}, 5 \mathrm{~min}\right.$ at $40^{\circ} \mathrm{C}$, pH 6.7) -treated micellar casein $\left(25 \mathrm{~g}\right.$ protein $\left.\cdot \mathrm{kg}^{-1}\right)$ in SMUF (A). Each curve represents the mean of duplicate trials.
It has been proposed that partial disintegration of the casein network due to solubilisation of colloidal calcium phosphate might have been responsible for observed a maximum in $\tan \delta$ at $\mathrm{pH}$ of $\sim 5.0$ during acidification of heated skim milk $[2,23]$. In the present work, the incubation of micellar casein with Tgase had no effect on calcium and phosphate solubilisation on acidification but the Tgase-induced crosslinks impaired the hydration of the micelle at lower $\mathrm{pH}$ values (Fig. 3) and probably inhibited the ability of the casein strands to rearrange as the $\mathrm{pH}$ decreased below the gel point. It can be seen in Figure 1 that $\kappa$-casein in the milk micelle system is a good substrate for Tgase. Schorsch et al. [37] suggested that Tgase prevented disaggregation of casein micelles on acidification. Tgase-induced cross-linking between casein molecules at the surface of the micelle probably impaired the mobility and flexibility of the K-casein "hairs", reducing the volume spanned by the $\kappa$-casein and lessening its effects of steric stabilisation. Tgase promoted aggregation between micellar particles whose casein molecules were partly covalently linked together resulting in a higher gelation $\mathrm{pH}$ compared to the control [37].

\subsection{Effect of pre-incubation with Tgase on the conversion of micel- lar casein into sodium caseinate}

In the previous sections we have suggested that incubation of micellar casein at neutral $\mathrm{pH}$ induces intra-micellar casein cross-linking, the degree of which is timerelated (Fig. 1). The viscosity profile of Tgase $\left(10 \mathrm{~g} \cdot \mathrm{kg}^{-1}, 5 \mathrm{~min}, 40^{\circ} \mathrm{C}, \mathrm{pH} 6.7\right.$ before inactivation at $78{ }^{\circ} \mathrm{C}$ for $\left.30 \mathrm{~min}\right)$ -treated micellar casein $\left(25 \mathrm{~g}\right.$ protein $\left.\cdot \mathrm{kg}^{-1}\right)$ in SMUF is shown in Figure 7. Both the Tgase-treated sample and the control (no Tgase treatment) showed Newtonian viscosity behaviour with apparent viscosities of $3.06 \pm 0.2$ and $3.11 \pm 0.2 \mathrm{mPa} . \mathrm{s}$, respectively at a shear rate of $100 \mathrm{~s}^{-1}$. The absence of a viscosity effect of the Tgase on micellar casein at $\mathrm{pH} 6.7$ indicates an absence of inter-micellar cross-linking, which agrees with the findings Schorsch et al. [37].

We have also ascertained that if the Tgase is active during the acidification of micellar casein markedly stronger acid gels are achieved, possibly due to secondary Tgase-induced cross-linking at $\mathrm{pH}$ values acid to the gel point [22]. Attempts were made to convert the washed acid curd formed from micellar casein, acidified 
(using $\mathrm{HCl}$ ) in the presence of Tgase to sodium caseinate, but these proved to be impossible under our conditions. A stable colloidal suspension could not be achieved, turbidity was high and high sediment levels were the norm, possibly due to Tgase-induced secondary cross-linking. However, if micellar casein was incubated with Tgase at neutral $\mathrm{pH}$ for limited time periods, heated to inactivate the enzyme, subsequently acidified, the curd washed and then converted, a viscous sodium caseinate with minimal sediment could be produced. It is probable that the extended heating regime employed to inactivate the enzyme $\left(78^{\circ} \mathrm{C}\right.$ for $\left.30 \mathrm{~min}\right)$ would have denatured a proportion of the trace amounts of whey protein present in the micellar casein dispersions. However sodium caseinate produced from micellar casein which was not treated with Tgase (control) was also heated and would therefore contain small amounts of denatured whey protein. No major increase in viscosity was observed (Fig 7).

A typical rheological profile for high-viscosity sodium caseinate $\left(50 \mathrm{~g}\right.$ protein $\left.\cdot \mathrm{kg}^{-1}\right)$ produced through limited Tgase-induced intra-micellar cross-linking of micellar casein at pH 6.7 is outlined in Figure 7. The control product made from micellar casein $(25 \mathrm{~g}$ protein $\cdot \mathrm{kg}^{-1}$ ) in SMUF incubated at $78^{\circ} \mathrm{C}$ for $30 \mathrm{~min}$ showed Newtonian viscosity behaviour with an apparent viscosity of 7.6 \pm $0.4 \mathrm{mPa}$.s at a shear rate of $100 \mathrm{~s}^{-1}$. The sodium caseinate $\left(50 \mathrm{~g}\right.$ protein $\left.\cdot \mathrm{kg}^{-1}\right)$ made from micellar casein $\left(25 \mathrm{~g}\right.$ protein $\left.\cdot \mathrm{kg}^{-1}\right)$ in SMUF incubated for $5 \mathrm{~min}$ at $40^{\circ} \mathrm{C}$ with Tgase $\left(10 \mathrm{~g} \cdot \mathrm{kg}^{-1}\right)$ at $40^{\circ} \mathrm{C}$ before enzyme inactivation at $78^{\circ} \mathrm{C}$ for $30 \mathrm{~min}$ showed significantly increased viscosity (an apparent viscosity of $64.6 \pm 33 \mathrm{mPa}$.s at a shear rate of $100 \mathrm{~s}^{-1}$ ) and fitted the Herschel Bulkley model, with shear-thinning behaviour and a yield stress [47].

Highly viscous behaviour was present in all Tgase-treated samples with a mean viscosity between treatments (5-60 min incubation) of $58.3 \pm 7.3 \mathrm{mPa} . \mathrm{s}$, at $100 \mathrm{~s}^{-1}$. Sodium caseinate $\left(10 \mathrm{~g}\right.$ protein $\left.\cdot \mathrm{kg}^{-1}\right)$ produced by limited Tgase-induced cross-linking of micellar casein (5-60 min incubation) showed increased turbidity $\left(\mathrm{A}_{600}\right.$ of 1.37 ; mean between treatments, \pm 0.29 ; standard deviation between treatments) and ethanol stability $(621$; mean between treatments, $\pm 18 \mathrm{~mL} \cdot \mathrm{L}^{-1}$; standard deviation between treatments) compared to the control, $0.28 \pm$ 0.01 and $530 \pm 7 \mathrm{~mL} \cdot \mathrm{L}^{-1}$, respectively. It is probable that Tgase-induced cross-links (irreversible) were formed between the various caseins in the micelle, which persisted through the acidification and subsequent re-neutralisation steps of sodium caseinate production. This would account for the higher viscosities and turbidities observed in Tgase-treated samples. The ethanol stability of standard sodium caseinate $\left(\sim 530 \mathrm{~mL} \cdot \mathrm{L}^{-1}\right)$ has been attributed to the preferential aggregation of $\alpha_{s 2^{-}}$and $\kappa$-casein [30], the $\alpha_{s 1}$ - and $\beta$-casein fractions remaining in solution. Increased stability to ethanol of sodium caseinate with limited Tgase-induced crosslinking can therefore be interpreted as a decrease in mobility of the ethanol susceptible casein fractions ( $\alpha_{\mathrm{s} 2^{-}}$and $\kappa$-casein) preventing aggregation/precipitation at $530 \mathrm{~mL} \cdot \mathrm{L}^{-1}$ ethanol.

The increased stability of Tgase-treated casein micelles against dissociation by heat, rennet coagulation and a combination of ethanol ( $35 \%$ ethanol concentration) and heat $\left(>60^{\circ} \mathrm{C}\right)$ was previously shown by O'Sullivan et al [33] and attributed to crosslinking between $\mathrm{\kappa}$-casein and other casein molecules on the micelle surface.

However, precipitation occurred at a higher level of ethanol $\left(621 \mathrm{~mL} \cdot \mathrm{L}^{-1}\right)$, and soluble protein levels $\left(1.27 \mathrm{mg} \cdot \mathrm{mL}^{-1}\right)$ in ethanol were markedly lower in the Tgasetreated samples than for the standard sodium caseinate $\left(3.46 \mathrm{mg} \cdot \mathrm{mL}^{-1}\right)$ at the same ethanol concentration. The lower levels of ethanol soluble proteins at $620 \mathrm{~mL} \cdot \mathrm{L}^{-1}$ ethanol following Tgase-treatment induced crosslinks compared to the standard sodium caseinate indicates that following Tgase-treatment, some of the $\alpha_{\mathrm{s} 1}$ - and $\beta$-casein fractions may have been cross-linked to the more ethanol insoluble fractions and so lost their inherent ethanol stability.

Due to the requirement for heat inactivation of the enzyme prior to processing, the relevance of Tgase as a method of producing high viscosity sodium caseinate becomes suspect due to the concomitant inclusion of denatured whey proteins. It is possible that 
a high viscosity proteinate (containing casein and whey protein) would be more applicable to the process as described here. Alternatively, it may have some merit to leave the enzyme active during the process, if the time between the initial acidification and pasteurisation following the curd washing was sufficiently fast (commercial acid casein production). However, cross-linking in a curd situation would be very difficult to inhibit or control.

\section{CONCLUSION}

The use of Tgase to improve some of the functional properties of micellar casein or its sodium caseinate derivative may have some commercial applications provided sufficient control can be exerted. Significant cross-linking may be encouraged if acid gel formation is of interest. Low crosslinking levels within the casein micelle are required for improving the water-binding properties of the resulting sodium caseinate.

Acknowledgements: The authors are indebted to J. Mounier for translating the abstract into French and J. Wildner for technical help.

\section{REFERENCES}

[1] Auty M.A.E., O’Kennedy B.T., Allan-Wojtas P., Mulvihill D.M., The application of microscopy and rheology to study the effect of milk salt concentration on the structure of acidified micellar casein systems, Food Hydrocolloids 19 (2005) 101-109.

[2] Biliaderis C.G., Khan M.M., Blank G., Rheological and sensory properties of yoghurt from skim milk and ultrafiltered retentates, Int. Dairy J. 2 (1992) 311-323.

[3] Creamer L.K., Matheson A.R., Effect of heat treatment on the proteins of pasteurized skim milk, N. Z. J. Dairy Sci. Technol. 15 (1980) 37-49.

[4] Davies D.T., White J.C.D., The stability of milk proteins to heat: 1 . Subjective measurement of heat stability of milk, J. Dairy Res. 33 (1966) 67-81.

[5] De Kruif C.G., Attractive interactions and aggregation in food dispersions, in: Dickenson E., Rodriquez Patino J.M. (Eds.), Food Emulsions and Foams; interfaces, interactions and stability, Royal Society of Chemistry, Great Britain, 1999, pp. 29-44.
[6] Færgemand M., Qvist K.B., Transglutaminase: Effect on rheological properties, microstructure and permeability of set style acid skim milk gel, Food Hydrocolloids 11 (1997) 287-292.

[7] Færgemand M., Otte J., Qvist K.B., Enzymatic cross-linking of whey proteins by a $\mathrm{Ca} 2+-$ independent microbial transglutaminase from Streptomyces lydicus, Food Hydrocolloids 11 (1997) 19-25.

[8] Færgemand M., Sorensen M.V., Jorgensen U., Budolfsen G., Qvist K.B., Transglutaminase: effect on instrumental and sensory texture of set style yoghurt, Milchwissenschaft 54 (1999) 563-566.

[9] Famelart M.H., Lepesant F., Gaucheron F., Le Graët Y., Schuck P., pH-Induced physiochemical modifications of native micellar caseinate suspensions: Influence of aqueous phase, Lait 76 (1996) 445-460.

[10] Folk J.E., Chung S.H., Transglutaminases, Methods in Enzymology 113 (1985) 358-375.

[11] Horne D.S., Formation and structure of acidified milk gels, Int. Dairy J. 9 (1999) 261268.

[12] IDF, Determination of dry matter in cheese and processed cheese, Standard FIL-IDF 4: Int. Dairy Fed., Brussels, Belgium, 1958.

[13] IDF, Determination of total phosphorus content, Standard FIL-IDF 33C: Int. Dairy Fed., Brussels, Belgium, 1987.

[14] IDF, Milk: Determination of nitrogen content, Part 3: Block digestion method (Semimicro rapid routine method), Annex-Modified procedure for milk products. Standard FIL-IDF 20B: Int. Dairy Fed., Brussels, Belgium, 1993.

[15] Imm J.Y., Lian P., Lee C.M., Gelation and water binding properties of transglutaminase-treated skim milk powder, J. Food Sci. 65 (2000) 200-205.

[16] Jenness R., Koops J., Preparation and properties of a salt solution which simulates milk ultrafiltrate, Neth. Milk Dairy J. 16 (1962) 153-164.

[17] Kelly P.M., O'Kennedy B.T., The effect of casein/whey protein ratio and minerals on the rheology of fresh cheese gels using a model system, Int. Dairy J. 11 (2001) 525-532.

[18] Kelly P.M., Kelly J., Mehra R., Oldfield D.J., Raggett E., O'Kennedy B.T., Implementation of integrated membrane processes for pilot scale development of fractionated milk components, Lait 80 (2000) 139-153.

[19] Kinsella J.E., Milk proteins: Physiochemical and functional proerties, Crit. Rev. Food Sci. Nutr. 21 (1984) 197-262.

[20] Laemmli U.K., Cleavage of structural proteins during the assembly of the head of bacteriophage T4, Nature 227 (1970) 680-685. 
[21] Lorenzen P.C., Mautner A., Schlimme E., Auswirkung der enzymatischen Quernetzung von Milchproteinen auf die resultierenden Eigenschaften von Joghurterzeugnissen, Kieler Milchwirtsch. Forsch. 51 (1999) 89-97.

[22] Lorenzen P.C., Neve H., Mautner A., Schlimme E., Effect of enzymatic cross-linking of milk proteins on functional properties of set-style yoghurt, Int. J. Dairy Technol. 55 (2002) 152-157.

[23] Lucey J.A., Tamehana M., Singh H., Munro P.A., Rheological properties of milk gels formed by a combination of rennet and gluconod-lactone, J. Dairy Res. 67 (2000) 415-427.

[24] Muir D.D., Sweetsur A.W.M., The influence of naturally occurring levels of urea on the heat stability of bulk milk, J. Dairy Res. 43 (1976) 495-499.

[25]Mulvihill D.M., Caseins and caseinates: manufacture, in: Fox P.F. (Ed.), Developments in Dairy Chemistry, vol.4: Functional Proteins, Elsevier Applied Science Publishers, London, UK, 1989, pp. 97-130.

[26] Murphy F., O’Kennedy B.T., Mehra R., Formation of heat-induced reactive thiol groups and subsequent acid-induced cold gelation of $\beta$-lactoglobulin enriched solutions, Ir. J. Agric. Food Res. 43 (2004) 137.

[27] Nieuwenhuijse J.A., Sjollema A., van Boekel M.A.J.S., van Vliet T., Walstra P., The heat stability of concentrated skim milk, Neth. Milk Dairy J. 45 (1991) 193-224.

[28] Nonaka N., Sakamoto H., Toiguchi S., Kawajiri H., Soeda T., Motoki M., Sodium caseinate and skim milk gels formed by incubation with microbial transglutaminase, J. Food Sci. 57 (1992) 1214-1218.

[29] O'Kennedy B.T., Halbert C., Kelly P.M., Formation of whey protein particles using calcium phosphate and their subsequent stability to heat, Milchwissenschaft 56 (2001) 625-628.

[30] O'Kennedy B.T., Cribbin M., Kelly P.M., Stability of sodium caseinate to ethanol, Milchwissenschaft 56 (2001) 680-684.

[31] O'Sullivan M., Lorenzen P.C., O'Connell J.E., Kelly A.L., Schlimme E., Fox P.F., Influence of transglutaminase on the heat stability of milk, J. Dairy Sci. 84 (2001) 13311334.

[32] O'Sullivan M.M., Kelly A.L., Fox P.F., Effect of transglutaminase on the heat stability of milk: a possible mechanism, J. Dairy Sci. 85 (2002) 1-7.

[33] O'Sullivan M.M., Kelly A.L., Fox P.F., Influence of transglutaminase treatment on some physico-chemical properties of milk, J. Dairy Res. 69 (2002) 433-442.
[34] Panouillé M., Nicolai T., Durand D., Heat induced aggregation and gelation of casein submicelles, Int. Dairy J. 14 (2004) 297-303.

[35] Pires M.S. Orellana G.A. Gatti C.A., Rennet coagulation of casein micelles and heated casein micelles: action of $\mathrm{Ca}^{2+}$ and $\mathrm{pH}$, Food Hydrocolloids 13 (1999) 235-238.

[36] Schorsch C., Carrie H., Clark A.H., Norton I.T., Cross-linking casein micelles by a microbial transglutaminase conditions for formation of transglutaminase-induced gels, Int. Dairy J. 10 (2000) 519-528.

[37] Schorsch C., Carrie H., Norton I.T., Crosslinking casein micelles by a microbial transglutaminase: influence of cross-links in acid-induced gelation, Int. Dairy J. 10 (2000) 529-539.

[38] Sharma R., Lorenzen P.C., Qvist K.B., Influence of transglutaminase treatment of skim milk on the formation of $\varepsilon$-( $\gamma$-Glutamyl)Lysine and the susceptibility of individual proteins towards cross-linking, Int. Dairy J. 11 (2001) 785-793.

[39] Singh H., Creamer L.K., Influence of concentration of milk solids on the dissociation of micellar $\kappa$-casein on heating reconstituted skim milk at $120{ }^{\circ} \mathrm{C}$, J. Dairy Res. 58 (1991) 99-105.

[40] Snoeren T.H.M., Klok H.J., van Hooydonk C.M., Damman A.J., The voluminosity of casein micelles, Milchwissenschaft 39 (1984) 461-463.

[41] Tarodo de la Fuente B., Alais C., Solvation of casein in bovine milk, J. Dairy Sci. 58 (1974) 293-299.

[42] van Boekel M.A.J.S., Nieuwenhuijse J.A., Walstra P., The heat coagulation of milk. 1. Mechanisms, Neth. Milk Dairy J. 43 (1986) 97-127.

[43] van Hooydonk A.C.M., Hagedoorn H.G., Boerrigter I.J., pH-induced physico-chemical changes in casein micelles in milk and their effect on renneting 1 . Effect of acidification on physico-chemical properties, Neth. Milk Dairy J. 40 (1986) 281-296.

[44] van Vliet T., van Dijk H.J.M.,Zoon P., Walstra P., Relation between syneresis and rheological properties of particle gels, Colloid Polym. Sci. 269 (1991) 620-627.

[45] Vasbinder A.J., Rollema H.S., Bot A., de Kruif C.G., Gelation mechanism of milk as influenced by temperature and $\mathrm{pH}$; studied by the use of transglutaminase cross-linked casein micelles, J. Dairy Sci. 86 (2003) 15561563.

[46] Walsh-O'Grady C.D., O'Kennedy B.T., Fitzgerald R.J., Lane C.N., A rheological study of acid-set "simulated yoghurt milk" gels prepared from heat- or pressure- treated milk proteins, Lait 81 (2001) 637-650.

[47] Whorlow R.W., Rheological Technique, 2nd edn., Ellis Horwood, New York, 1992. 